\title{
QUANTIFICATION AND DISTRIBUTION OF VIBRIO SPECIES IN WATER FROM AN ESTUARY IN CEARÁ-BRAZIL IMPACTED BY SHRIMP FARMING
}

\author{
Renata A. Costa ${ }^{\text {*; }}$; Giselle C. Silva ${ }^{2}$; Jackson R. O. Peixoto ${ }^{2}$; Gustavo H. F. Vieira ${ }^{3}$ and Regine H. S. F. Vieira ${ }^{2}$ \\ ${ }^{1}$ Universidade Federal do Ceará \\ Estudante de Doutorado em Engenharia de Pesca. Bolsista PROPAG \\ (Av. Abolição 3207, Meireles, 60165-081 Fortaleza, CE, Brasil) \\ ${ }^{2}$ Universidade Federal do Ceará - Instituto de Ciências do Mar (LABOMAR) \\ Laboratório de Microbiologia Ambiental e do Pescado \\ (Av. Abolição 3207, Meireles, 60165-081 Fortaleza, CE, Brasil) \\ ${ }^{3}$ Universidade Estadual Vale do Acaraú - Departamento de Biologia \\ (Av. da Universidade 850, Campus da Betânia, 62040-370 Sobral, CE, Brasil) \\ *Corresponding author: renata.albuq@gmail.com.
}

\begin{abstract}
A B S T R AC T
Vibrios were quantified and their distribution determined for the estuary of the Coreaú river, in Northeastern Brazil, based on 24 water samples collected between June and October 2005. The most probable number of vibrios per $100 \mathrm{~mL}$ ranged from $230 \times 10^{3}$ to $240 \times 10^{11}$. The $\mathrm{pH}$ value was the environmental factor most strongly associated with the abundance of vibrios. Sixty-two vibrio strains were isolated belonging to 15 species ( 6 of which observed in June-September and 8 in October). The most frequently isolated species were $V$. parahaemolyticus and $V$. cholerae.
\end{abstract}

\section{RESUMO}

Foram realizadas análises concernentes à quantificação e distribuição de Vibrio em 24 amostras de água do estuário do Rio Coreaú (CE) no período de junho a novembro de 2005. O Número Mais Provável (NMP/100 mL) de Vibrio oscilou de $230 \times 10^{3}$ a $240 \times 10^{11}$. O pH foi o fator ambiental que mais favoreceu ao aumento da microbiota de Vibrio. Foram isoladas 62 cepas de Vibrio, sendo observada uma distribuição de sete espécies nos meses de junho a setembro, e oito espécies no mês de outubro. As espécies mais freqüentes nos isolamentos foram V. parahaemolyticus e V. cholerae.

Descriptors: Vibrio, Estuary, Shrimp farming.

Descritores: Vibrio, Estuário, Carcinicultura.

\section{INTRODUCTION}

Bacteria of the genus Vibrio are ubiquitous in estuaries (HEIDELBERG et al., 2002; THOMPSON et al., 2004; BLACKWELL; OLIVER, 2008) and have been known to infect cultivated marine shrimp (AGUIRRE-GUZMÁN et al., 2001; ALAVANDI et al., 2006; VASEEHARAN et al., 2008). According to Alvarez et al. (2003), the shrimp farming industry is permanently on guard against infectious diseases and other setbacks that might harm production.

Vibrios are not only a major economic threat to marine shrimp farming, but represent a public health concern as they are easily transmitted to humans through the consumption of seafood (BLACKSTONE et al. 2003; FUENZALIDA et al., 2007; LEE et al., 2008).
On the other hand, shrimp farming in estuaries is generally associated with the outlet of nutrients and organic matter into the environment, causing a negative impact on the native microbiota. Research on the impact of shrimp farming has shown that discharges from farms significantly raise the levels of nutrients in coastal environments (PÁEZ-OSUNA et al., 1998; TROTT; ALONGI, 2000; PÁEZ-OSUNA, 2001). Sousa et al. (2006) observed increasing vibrio counts in water samples from an estuary in Ceará exposed to the discharge of nutrients from shrimp farms.

Thus, the objective of the present study was to quantify and determine the distribution of vibrio species in an estuary in Ceará-Brazil impacted by shrimp farming. 


\section{Materials and Methods \\ Sampling}

Twenty-four water samples were collected from two locations, twelve at each location (Location 1 $3^{\circ} 5^{\prime} 39.3$ ' $\mathrm{S}, \quad 40^{\circ} 49^{\prime} 8.05^{\prime} \mathrm{W}$ and Location 2 $3^{\circ} 5$ '46.42”'S, 4049'7.78'W, Fig. 1) in the Coreaú river, $250 \mathrm{~km}$ west of Fortaleza, Ceará, bimonthly between June and October 2005. The period covered the end of the rainy season and 4 months of the dry season. The samples were collected in sterilized amber-colored 1-liter vials and stored in a refrigerator until the moment of analysis, no longer than 2 hours after sampling.

\section{Sample Preparation}

The samples were diluted at $1: 9$ in $0.85 \%$ saline solution in order to prepare serial decimal dilutions from $10^{-1}$ to $10^{-8}$.

\section{Quantification of Vibrio}

The multiple-tube technique was used to determine the most probable number (MPN) of vibrios in the samples (KAYSNER; DEPAOLA, 2004). Presumptive tests were performed with $1 \mathrm{~mL}$ of each dilution $\left(10^{-1}\right.$ to $\left.10^{-8}\right)$ inoculated in alkaline peptone water containing $1 \% \mathrm{NaCl}(\mathrm{pH} 8.5)$, followed by incubation for 24 hours at $35^{\circ} \mathrm{C}$. The confirmatory tests were made by spread-plating $0.1-\mathrm{mL}$ inoculates from tubes with positive growth onto thiosulfatecitrate-bile salts-sucrose (TCBS) agar, followed by incubation for 18 hours at $35^{\circ} \mathrm{C}$. MPN was calculated by multiplying the critical series by the average dilution, and results were expressed as MPN/100mL (GARTHRIGHT, 2001).

\section{Isolation and Identification of Vibrio}

Approximately three colonies (saccharosepositive and negative) were selected from the TCBS plate and isolated in tryptic soy agar (TSA) containing $1 \% \mathrm{NaCl}$, followed by incubation for 24 hours at $35^{\circ} \mathrm{C}$. Pure strains were submitted to phenotypical identification as described in the literature (ALSINA; BLANCH, 1994a; ALSINA; BLANCH, 1994b). Biochemical testing with arginine dihydrolase, lysine and ornithine decarboxylase was used as screening to select lineages for Alsina's identification key. The tests used to identify the species were as follows: oxidase, growth at $0,3,6,8$ and $10 \% \mathrm{NaC} 1$, sucrose acid, arabinose acid, mannitol acid, glucose gas, lactose acid, mannose acid, indole, citrate, Voges Proskauer test, ONPG (alfa-nitrophenyl- $\beta$-Dgalactopyronoside), growth at 4,35 and $40^{\circ} \mathrm{C}$, gelatinase, resistance to $\mathrm{O} / 12910 \mu \mathrm{g}$ and resistance to ampicillin $10 \mu \mathrm{g}$.

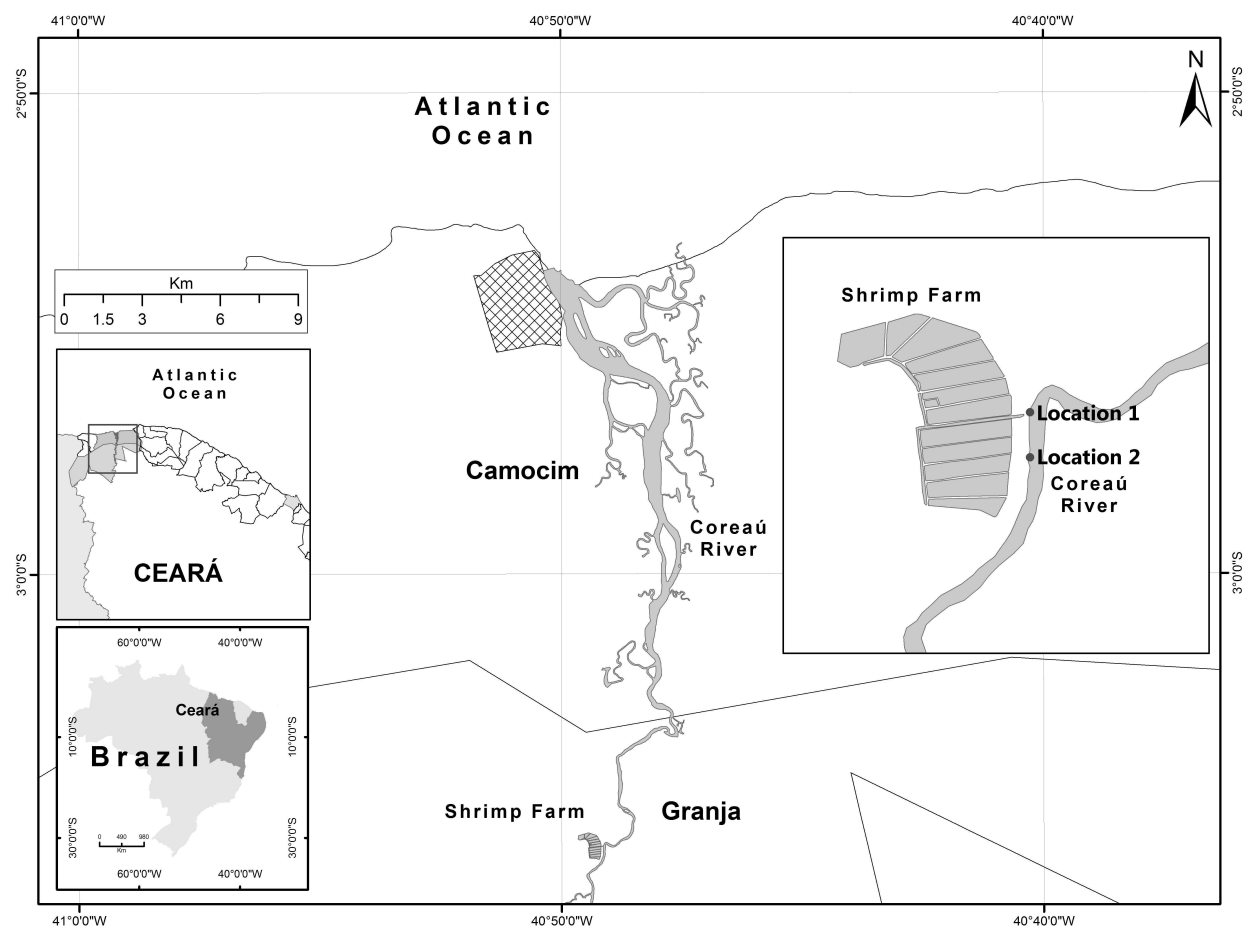

Fig. 1. Sampling points in the Coreaú river. 
Environmental Variables

Temperature, salinity and $\mathrm{pH}$ were measured with a $\mathrm{pH}$ meter (Hanna instruments $\mathrm{pH} 211$ ) and a handheld digital refractometer (Digit, model 211).

\section{Results}

The most probable number of vibrios $\left(\log _{10}\right.$ NMP) per $100 \mathrm{~mL}$ in water from sampling points 1 and 2 ranged from 6.36 to 10.04 and from 5.36 to 13.38 , respectively (Table 1$)$. The corresponding $\mathrm{pH}$ values were $6.53-8.22$ and 7.66-8.19. Small variations were observed for temperature $\left(28.7-31.6^{\circ} \mathrm{C}\right.$ and $\left.29.0-31.4^{\circ} \mathrm{C}\right)$, but variations for salinity were considerable $(0-36 \%$ and $1-43 \%$ o), respectively (Table 1).

Pearson's correlation coefficients ( $r$ ) between environmental variables ( $\mathrm{pH}$, temperature and salinity) and MPN of vibrios are shown in Table 2.

Altogether, 62 vibrio strains belonging to 15 species were isolated from the 24 water samples (Table 3). The predominant species were $V$. parahaemolyticus $(16.12 \%)$, V. cholerae $(14.51 \%)$ and V. alginolyticus $(12.9 \%)$.

Table 1. Most probable number $\left(\log _{10} \mathrm{MPN}\right)$ of vibrios per $100 \mathrm{~mL}$ water and corresponding environmental variables in 24 samples from the estuary of the Coreaú river, Ceará.

\begin{tabular}{ccccccccc}
\hline \hline Samples & \multicolumn{9}{c}{ Point 1 } & \multicolumn{5}{c}{ Point 2 } \\
\cline { 2 - 9 } & MPN & T. & pH & S. & MPN & T. & pH & S. \\
\hline 1 & 7,63 & 31,3 & 6,53 & 0 & 8,17 & 29,5 & 7,85 & 1 \\
2 & 6,36 & 28,7 & 7,58 & 0 & 9,66 & 30,2 & 7,83 & 1 \\
3 & 7,36 & 29,5 & 7,70 & 1 & 8,96 & 29,3 & 8,10 & 5 \\
4 & 10,04 & 29,4 & 7,57 & 1 & 7,36 & 31,4 & 7,28 & 14 \\
5 & 7,36 & 30,03 & 8,18 & 9 & 6,36 & 31,0 & 7,78 & 25 \\
6 & 7,20 & 31,0 & 7,45 & 13 & 5,36 & 30,5 & 7,66 & 24 \\
7 & 6,36 & 31,0 & 7,77 & 25 & 7,36 & 28,4 & 7,71 & 32 \\
8 & 8,63 & 29,9 & 8,22 & 24 & 6,63 & 30,4 & 7,72 & 30 \\
9 & 7,55 & 28,8 & 7,73 & 34 & 6,96 & 29,8 & 7,83 & 36 \\
10 & 6,96 & 30,3 & 7,79 & 30 & 7,47 & 29,3 & 7,76 & 30 \\
11 & 6,55 & 29,2 & 7,83 & 36 & 9,38 & 29,0 & 7,90 & 43 \\
12 & 8,46 & 29,7 & 7,74 & 33 & 13,38 & 29,6 & 8,19 & 34 \\
\hline
\end{tabular}

*T: Temperature; S: Salinity.

Table 2. Pearson's correlation coefficients (r) between environmental variables $\left(\mathrm{pH}\right.$, temperature $\left[{ }^{\circ} \mathrm{C}\right]$ and salinity $\left.[\% o]\right)$ and the most probable number (MPN) of vibrios per $100 \mathrm{~mL}$ water in 24 samples from the estuary of the Coreaú river, Ceará.

\begin{tabular}{ccc}
\hline \hline Point & Environmental & MPN/100mL de Vibrio \\
& Variables & \\
\hline \multirow{2}{*}{1} & $\mathrm{pH}$ & 0,5283 \\
& Temperature & $-0,2959$ \\
& Salinity & 0,1699 \\
2 & $\mathrm{pH}$ & 0,6670 \\
& Temperature & $-0,3332$ \\
& Salinity & $-0,0103$ \\
\hline
\end{tabular}

Table 3. Distribution of 15 vibrio species in 24 water samples from the estuary of the Coreaú river, Ceará, collected between June and October 2005.

\begin{tabular}{|c|c|}
\hline Month & Species \\
\hline June $(\mathrm{n}=12)$ & $\begin{array}{l}\text { Vibrio spp (3), V. cholerae (2), V. damsela (2), V. fluvialis (2), V. mimicus (1), V. hollisae (1), } \\
\text { V. anguillarum (1) }\end{array}$ \\
\hline July (n=11) & $\begin{array}{l}\text { V. cholerae (4), V. damsela (2), V. parahaemolyticus (1), Vibrio spp (1), V. carchariae (1), V. } \\
\text { harveyi (1), V. vulnificus (1) }\end{array}$ \\
\hline August ( $\mathrm{n}=11)$ & $\begin{array}{l}\text { V. parahaemolyticus (2), V. cholerae (2), V. splendidus (2), V. harveyi (2), Vibrio spp (1), V. } \\
\text { hollisae (1), V. fluvialis (1) }\end{array}$ \\
\hline September $(n=12)$ & $\begin{array}{l}\text { V. parahaemolyticus (4), Vibrio spp (3), V. alginolyticus (1), splendidus (1), V. cincinnatiensis } \\
\text { (1), V. metschnikovii (1), V. carchariae (1). }\end{array}$ \\
\hline October $(n=16)$ & $\begin{array}{l}\text { V. alginolyticus (7), V. parahaemolyticus (3), V. harveyi (1), V. cholerae (1), V. damsela (1), } \\
\text { carchariae (1), V. fluvialis (1), V. furnissi (1) }\end{array}$ \\
\hline
\end{tabular}




\section{Discussion}

The great abundance of vibrios in the estuary of the Coreaú river may be related to several anthropogenic effects, perhaps primarily to the increasing amount of nutrients and organic matter discharged by shrimp farms. Booming socioeconomic activities, such as shrimp farming and tourism, have exposed the estuary and surrounding mangrove lands to unprecedented impacts (MEIRELES; SILVA, 2002). However, according to Lacerda (2006), the amount of nitrogen and phosphate discharged into the Coreaú river by organized shrimp farming is much smaller than the amounts contributed by agriculture and animal husbandry. On the other hand, Das et al. (2004) reported the discharge of nutrients from shrimp farms along Indian estuaries to have caused severe impacts on the environment.

The highest MPN values were found in samples with high $\mathrm{pH}$ (8.22 at Point 1 and 8.19 at Point 2). In fact, Pearson's correlation coefficient between environmental variables and MPN indicates that high $\mathrm{pH}$ values were the environmental factor which most contributed to the increase in the abundance of vibrios in the Coreaú river. $\mathrm{pH}$ values in the range 8.4-8.6 are considered ideal for vibrio growth (DONOVAN; NETTEN, 1996). Gonçalves et al. (2004) observed a significant correlation between $\mathrm{pH}$ values (6.2-9.8) of water samples from the estuary of the Baía de São Marcos (São Luís, Maranhão, Brazil) and the amount of $V$. cholerae isolated.

The low salinity observed in samples collected in June may be explained by the influence of seasonal rainfall. However, in the dry season between August and October salinity rose as evaporation increased. As shown by Pearson's correlation coefficient, salinity and MPN values were not significantly correlated in our samples. In fact, according to Murakami et al. (1998), vibrios are indeed very flexible with regard to salinity.

The absence of a correlation between temperature and MPN values may be due to the modest variation $\left(2.9^{\circ} \mathrm{C}\right)$ observed. Serra et al. (2003) reported similar results in a study on the relation between vibrios and physicochemical parameters in the estuary of the Anil river (São Luís, Maranhão, Brazil) and attributed the absence of significant variation to the geographical location near the Equator. Vibrios are mesophilic and are most common in tropical coastal waters (HERVIO-HEATH et al., 2002). Cervino et al. (2004) also found that vibrios grow best in temperatures between 17 and $35^{\circ} \mathrm{C}$.

The distribution of vibrio species in our samples presented insignificant variations, probably because of the relatively stable temperature and $\mathrm{pH}$ values. Molitoris et al. (1985) studied the distribution of $V$. parahaemolyticus in the bay of Jakarta (Indonesia) and reported the species to be more abundant during the dry season. The present findings lend support to this observation since $V$. parahaemolyticus was most frequently isolated in samples collected in September and October. The presence of $V$. cholerae strains in our water samples also corroborates the findings of Thompson et al. (2003), who reported V. cholerae to be ubiquitous and abundant in aquatic environments, especially in coastal areas, estuaries and rivers. The authors also reported that $V$. cholerae has caused many deaths in Brazil over the past decade and suggest that $V$. cholerae strains may be successfully adapting to changes in environmental conditions.

The frequency with which vibrios were isolated from our samples may be compared to the results of Barbieri et al. (1999) who isolated a large number of $V$. alginolyticus, $V$. parahaemolyticus, $V$. cholerae non-O1 and $V$. vulnificus in water samples from two estuaries on the Italian Adriatic coast. The authors report that some of the most toxigenic strains have been associated with a range of infections, from gastroenteritis to severe septicemia.

The occurrence of $V$. harveyi in the Coreáu river may represent a concern to local shrimp farmers. The species has been a major etiologic agent in vibrio infections in shrimp populations and responsible for serious economic losses in Southeast Asia (CONEJERO; HEDREYDA, 2003).

Macián et al. (2000) found a great abundance of vibrios in seawater samples from Valencia, Spain, especially $V$. harveyi (24\% of strains), $V$. splendidus $(19 \%)$ and $V$. alginolyticus (8\%). This is comparable to our findings for the Coreaú river, with the exception of $V$. splendidus with only 3 strains isolated from water samples at $28.4-31.4^{\circ} \mathrm{C}$.

The occurrence of $V$. vulnificus in our samples is in accordance with Yano et al. (2004), who say the species is a typical component of the estuarine microbiota which has been implicated in food contamination and septicemia. In their study on the ecology of $V$. vulnificus in estuaries, Pfeffer et al. (2003) only isolated the species in samples at $15-27^{\circ} \mathrm{C}$, and reported the abundance of vibrios to be dependent mainly on temperature, turbidity and dissolved oxygen levels. Their results do not match our own since the only $V$. vulnificus strain isolated in our study came from a sample at more than $28^{\circ} \mathrm{C}$.

Vibrios were abundant during the entire study period. Although the study design did not include a control, the authors suspect the consistently high indices of vibrios may be explained by the discharge of nutrients from local shrimp farms. The frequent isolation and abundance of certain vibrio species in samples from the Coreaú river indicate a potential risk to intensive aquiculture and to public health, considering the amount of seafood extracted from the region for human consumption. 


\section{REFERENCES}

AGUIRRE-GUZMÁN, G.; VÁZQUEZ-JUÁREZ， R.; ASCENCIO, F. Differences in the susceptibility of American white shrimp larval substages (Litopenaeus vannamei) to four vibrio species. J Invertebr Pathol., v. 78, n. 4 , p. $215-219,2001$

ALAVANDI, S. V.; MANORANJITA, V.; VIJAYAN, K. K.; KALAIMANI, N.; SANTIAGO, T. C. Phenotypic and molecular typing of Vibrio harveyi isolates and their pathogenicity to tiger shrimp larvae. Letts appl. Microbiol., v. 43, n. 5, p. 566-570, 2006.

ALSINA, M.; BLANCH, A. R. A set of keys for biochemical identification of environment Vibrio species. J. appl. Bact., v. 76, n. 1, p. 79-85, 1994a.

ALSINA, M.; BLANCH, A. R. Improvement and update of a set of keys for biochemical identification of environmental Vibrio species. J. appl. Bact., v. 77, p. 719-721, 1994b.

ALVAREZ, R. J. D.; AGURTO, C; OBREGÓN， J.; PEROZA, L. Detección de Baculovirus penaei y de casos de vibriosis em Litopenaeus vannamei and $L$. stylirostris en uma granja de la costa occidental de Venezuela. Revta cient. FCV-LUZ, v. 13, n. 4, p. 255262, 2003.

BARBIERI, E.; FALZANO, L.; FIORENTINI, C.; PIANETTI, A.; BAFFONE, W.; FABBRI, A.; MATARRESE, P.; CASIERE, A.; KATOULI, M.; KÜHN, I.; MÖLLBY, R.; BRUSCOLINI, F.; DONELLI, G. Occurrence, diversity, and pathogenicity of halophilic Vibrio spp. and non-O1 Vibrio cholerae from estuarine waters along the Italian Adriatic Coast. Appl. environ.Microbiol., v. 65, n. 6, p. 2748, 2753, 1999.

BLACKSTONE, G. M.; NORDSTROM, J. L.; VICKERY, M. C.; BOWEN, M. D.; MEYER, R. F.; DEPAOLA, A. Detection of pathogenic Vibrio parahaemolyticus in oyster enrichments by real time PCR. J Microbiol Meth., v. 53, n. 2, p. 149-155, 2003.

BLACKWELL, K. D.; OLIVER, J. D. The ecology of Vibrio vulnificus, Vibrio cholerae, and Vibrio parahaemolyticus in North Carolina estuaries. J. Microbiol., v. 46, n. 2, p. 146-153, 2008.

CERVINO, J. M.; HAYES, R. L.; POLSON, S. W.; POLSON, S. C.; GOREAU, T.J.; MARTINEZ, R. J; SMITH, G. W. Relationship of Vibrio species infection and elevated temperatures to yellow blotch/band disease in Caribbean corals. Appl. environ. Microbiol., v. 70, n. 11, p. 6855-6864, 2004.

CONEJERO, M.J.U.; HEDREYDA, C. T. Isolation of partial toxR gene of Vibrio harveyi and design of toxR-targeted PCR primers for species detection. J. appl. Microbiol., v. 95, n. 3, p. 602-611, 2003.

DAS, B.; KHAN, Y. S.; DAS, P. Environmental impact of aquaculture-sedimentation and nutrient loadings from shrimp culture of the southeast coastal region of the Bay of Bengal. J environ. Sci., (China), v. 16, n. 3, p. 466470, 2004

DONOVAN, T. J.; NETTEN, P. Culture media for the isolation and enumeration of pathogenic Vibrio species in food and environmental samples. Int. J. Food Microbiol., v. 26, p. 77-91, 1995.

FUENZALIDA, L.; ARMIJO, L.; ZABALA, B.; HERNÁNDEZ, C.; RIOSECO, M. L.; RIQUELME, C.;
ESPEJO, R. T. Vibrio parahaemolyticus strains isolated during investigation of the summer 2006 seafood related diarrhea outbreaks in two regions of Chile. Int. J. Food Microbiol., v. 117, p. 270-275, 2007.

GARTHRIGHT, W. E. Appendix 2: most probable number from serial dilutions. In: FOOD AND DRUG ADMINISTRATION - FDA. Bacteriological analytical manual on line. FDA/CFSAM, 2001. Available: <http://www.cfsan.fda.gov/ edam/bam-a2.html>. Accessed: 06/09/2004.

GONCALVES, E. G. R.; LOPES, M. J. S.; OLIVEIRA, E. G.; HOFER, E. Avaliação de Vibrio cholerae com o zooplâncton de águas estuárias da Baía de São Marcos/ São Luís - MA, Brasil. Rev. Soc. Bras. Med. Trop., v. 37, n. 4, p. 318-323, 2004.

HEIDELBERG, J; HEIDELBERG, K. B; COLWELL, R. R. Bacteria of the gamma-subclass Proteobacteria associated with zooplankton in Chesapeake Bay. Appl. environ. Microbiol., v. 68, p. 5498-5507, 2002.

HERVIO-HEATH, D.; COLWELL, R. R.; DERRIEN, A.; ROBERT-PILLOT, A. FOURNIER, J. M.; POMMEPUY, M. Occurrence of pathogenic vibrios in coastal areas of France. J. appl. Microbiol., v. 92, p. 1123-1135, 2002.

KAYSNER, C. A.; DEPAOLA JR., A. Vibrio cholerae, V. parahaemolyticus, $V$. vulnificus, and other Vibrio spp. 2004. Available:< http://www.cfsan.fda.gov/ ebam/bam9.html\#authors> Accessed: 10/01/2006.

LACERDA, L. D. Inputs of nitrogen and phosphorus to estuaries of northeastern Brazil from intensive shrimp farming. Braz. J. aquat. Sci. Technol., v. 10, n. 2, p. 13$27,2006$.

LEE, J-K.; JUNG, D-W.; EOM, S-Y.; OH, S-W; KIM, Y.; KWAK, H-S.; KIM, Y-H. Occurrence of Vibrio parahaemolyticus in oysters from Korean retail outlets. Food Control, v. 19, p. 990-994, 2008.

MACÍAN, M. C.; ROSA AZNAR, C. R. A.; GARAY, E. AND PUJALTE, M. J. Identification of Vibrio spp (other than $V$. vulnificus) recovered on CPC agar from marine natural samples. Int. Microbiol., v. 3, p. 51-53, 2000.

MEIRELES, A. J. A.; VICENTE DA SILVA, E. Abordagem geomorfológica para a realização de estudos integrados para o planejamento e gestão em ambientes flúviomarinhos. Scripta Nova. Revista electrónica de geografía y ciencias sociales, Universidad de Barcelona, v. 6, n. $118,2002$.

MOLITORIS, E.; JOSEPH, S. W.; KRICHEVSKY, M.; SINDHUHARDJA, W.; R. R. COLWELL. Characterization and distribution of Vibrio alginolyticus and Vibrio parahaemolyticus isolated in Indonesia. Appl. environ. Microbiol., v. 50, n. 6, p. 1388-1395, 1995.

MURAKAMI, K.; FUSE, H.; TAKIMURA, O.; KAMIMURA, K.; YAMAOKA, Y. Phylogenetic analysis of marine environmental strains of Vibrio that produce aerobactin. J. mar. Biotechnol., v. 6, n. 2, p. 76-79, 1998.

PÁEZ-OSUNA, F.; GUERRERO-GALVÁN, S. R.; RUIZFERNÁNDEZ, A. C. The environmental impact of shrimp aquaculture and the coastal pollution in Mexico. Mar. Pollut. Bull., v. 36, n. 1, p. 65-75, 1998.

PÁEZ-OSUNA, F. The environmental impact of shrimp Aquaculture: Causes, effects, and mitigating alternatives. Environ. Mgmt, v. 28, n. 1, p. 131-140, 2001. 
PFEFFER, C. S.; HITE, M. F.; OLIVER, J. D. Ecology of Vibrio vulnificus in estuarine waters of Eastern North Carolina. . Appl. environ. Microbiol., v. 69, n. 6, p. 3526-3531, 2003.

SERRA, C. L. M.; CAVALCANTE, P. R.; ALVES, L. M. C.; NASCIMENTO, A.R.; DINIZ, S.C.C.S. Avaliação de parâmetros físico-químicos e pesquisa de Vibrio parahaemolyticus em águas do estuário do rio Anil (São Luís, Estado do Maranhão). Acta Scientiarum. Biol. Sci., v. 25, n. 2, p. 261-266, 2003.

SOUSA, O. V.; MACRAE, A.; MENEZES, F. G.; GOMES, N. C. M.; VIEIRA, R. H. S.; MENDONÇA-HAGLER, L.C.S. The impact of shrimp farming effluent on bacterial communities in mangrove waters, Ceará, Brazil. Mar. Pollut. Bull., v. 52, p. 1725-1734, 2006.

THOMPSON, F. L.; TETSUYA, I.; SWINGS, J. Biodiversity of vibrios. Microbiol. Mol. Biol. Revs, v. 68, n. 3, p. 403-431, 2004.

THOMPSON, F. L.; THOMPSON, C. C.; VICENTE, A. C. P.; THEOPHILO, G. N. D; HOFER, E. ; SWINGS, J. Genomic diversity of clinical and environmental Vibrio cholerae strains isolated in Brazil between 1991 and 2001 as revealed by fluorescent amplified fragment length polymorphism analysis. J. clin. Microbiol., v. 41, n. 5, p. 1946-1950, 2003.
TROTT, L.A.; ALONGI, D.M. The impact of shrimp pond efluent on water quality and phytoplankton biomass in a tropical mangrove estuary. Mar. Pollut. Bull., v. 40, n. 11 , p. 947-951, 2000.

TROTT, L. A.; ALONGI, D. M. The impact of shrimp pond efluent on water quality and phytoplankton biomass in a tropical mangrove estuary. Mar. Pollut. Bull., v. 40, n. 11, p. 947-951, 2000

VASEEHARAN, B.; RAFFIG HUSSIAN, M.; CHENG, J. C. RpoN gene, RAPD profile, antimicrobial resistance and plasmids of Vibrio anguillarum isolates from vibriosis infected Penaeus monodon. Letts Appl. Microbiol., v. 47, n. 5 , p. 380-385, 2008

YANO, Y.; YOKOYAMA, M.; SATOMI, M.; OIKAWA, H.; CHEN, S-S. Occurrence of Vibrio vulnificus in fish and shellfish available from markets in china. J. Food Protect., , v. 67, n. 8, p. 1617-1623, 2004.

(Manuscript received 19 May 2009; revised 14 December 2009; accepted 09 March 2010) 